\title{
"A Linguistic Study of the Implicit/Explicit Distinction of the Meanings of some Verses of the Holy Qur'an"
}

\section{By:}

\section{Abeer Hussein Youssef Ahmed}

Abstract:

El-Sharif (2011: 78-9) declares that in the case of religious discourse, recognizing the accurate meaning of the message is important because the followers then realize that they are obeying the commands of their religion correctly. The misinterpretation of the religious message can lead the believer to err, and errors can lead to harmful consequences for the believer and his society. Furthermore, some mistakes which are performed because of misunderstanding the religious message are considered sins.

So this research investigates the truth conditional content of the meanings of some verses of the Holy Qur'an. It also identifies the explicit content and the implicit content using the available contextual and inferential resources and using the relevance - theoretic comprehension strategy to reach the intended interpretation of some meanings of the verses. Views surveyed include the explicature/implicature distinction developed within the cognitively-based relevance theory approach to utterance interpretation are used to interpret some of the verses of the Holy Qur'an.

\section{Key Words:}

\section{Relevance Theory - Implicature - Explicature - Holy Qur'an}

\section{Introduction:}

Sperber \& Wilson (1986:1) mention that Relevance Theory gives us a way of making our understanding more explicit. In Groefsema (1992: 48), Sperber \& Wilson argue that the linguistic content of an utterance undetermines its propositional content. They say that linguistic coding and decoding is involved in communication, the addressee can only take the output of the linguistic decoding process as a piece of evidence about the communicator's intention. 


\section{DR Abeer Hussein Yousse}

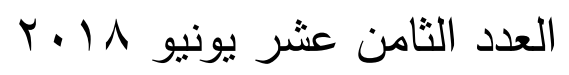

The data is analyzed along several dimensions, using theoretical insights of the Relevance Theory to explain that the speakers provide evidence of their intentions to convey a certain meaning; the data for the present research are gathered from some verses of the Holy Qur'an translated by Muhammad Taqi-ud-Ain (1997) and Abdullah Yusuf Ali (1999).

\section{Introductory Information of Relevance Theory}

Sperber and Wilson (1995: 55) said :"It seems that human cognition is aimed at improving the individual's knowledge of the world. This means adding more information, information that is more accurate, more easily retrievable, and more developed in areas of greater concern to the individual". Sperber \& Wilson (2012: 62) proposed that:

Relevance is used in a technical sense which is not meant to capture any of the ordinary senses of the world. These inputs may be external stimuli (e.g. a smell, the sound of an utterance) or internal representation which may undergo further processing (e.g. the recognition of a smell, a memory, the linguistic decoding of an utterance).

Sperber and Wilson (2012: 63) state that "relevance is also a matter of degree, and we want to characterize it not only as a classificatory notion but also as a comparative one." Wilson (1999: 719) showed that the main purpose of relevance theory is to explain what makes people pay attention to information depending on a cognitive perspective and analyzed in terms of the notion of cognitive effect and processing effort. Wilson and Sperber (2002: 250) state also that relevance theory is based on the idea that "the expectations of relevance raised by an utterance are precise enough and predictable enough to guide the hearer towards the speaker's meaning." The theory also states that individuals will naturally react to an utterance (encoded message) by taking into account information that they believe is relevant to the content of the message. So, Sperber and Wilson (2012: 86) state that communication was 


\section{DR Abeer Hussein Yousse}

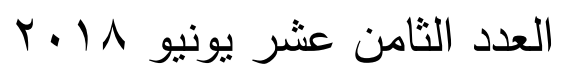

paraphrased as a process of coding and decoding in which the communicator or the speaker encodes a message into a signal that the audience then decodes.

Michael (2011:9) adds that this is further accompanied by the idea that the content of a message that is transmitted is considered relevant if that content is contextualized and needs only a small amount of effort from the hearer to understand it. Dor (2003: 699) also adds that the simplest way to understand this is that "the theory is one of cognitive cost-effect: it claims that human cognitive processes are geared to achieve the greatest possible cognitive effect for the smallest processing effort." By this way, Sperber and Wilson (1986: 32) said that the general objective of RT is to determine the mechanisms that are rooted in human psychology and explained how humans communicate with one another.

It is interesting to note that Sperber and Wilson (1987: 699) mention that the task of communication involves two ends: "as speakers we intend our hearers to recognize our intention to inform them of some state of affairs, as hearers, we try to recognize what it is that the speaker intends to inform us of". In addition, Zhonggang (2006: 45) mentions that relevance is a degree of notion: the degree of relevance that an audience obtains varies according to the amount of contextual effects the text contains, plus the processing effort the text costs. We may divide relevance into optimal relevance, strong relevance, weak relevance, and irrelevance in terms of its degree. 

Table (1): Graded Relevance

\begin{tabular}{|c|l|c|}
\hline Relevance & Contextual implication & Processing effort \\
\hline Optimal relevance & Contextual implication & $\begin{array}{c}\text { Without unnecessary } \\
\text { effort }\end{array}$ \\
\hline Strong relevance & Fully comprehensible & $\begin{array}{c}\text { With some necessary } \\
\text { effort }\end{array}$ \\
\hline Weak relevance & Implied & $\begin{array}{c}\text { Considerable effort } \\
\text { taken }\end{array}$ \\
\hline irrelevance & Vague and unclear & All effort is vain \\
\hline
\end{tabular}

(Adapted from Zhonggang, 2006: 45)

Accordingly, Cook (2005: 20) adds that Relevance Theory is a cognitive psychological approach which rests on some general assumptions about the mind .Wilson (1999: 719) analyzes communication as decoding the linguistic meaning of words and making inferences based on contextual assumptions of the meanings of these words. Michael (1991: 44) explains that Sperber and Wilson(1995) clearly differ from more conventional, Gricean, pragmatic theories in their characterization of what is explicit in verbal communication versus what is implicit. The conventional approach is to assume that any pragmatically determined aspect of utterance meaning is an implicature, but for Sperber and Wilson, pragmatic processes are involved in the development of propositional form, on the basis of which utterance meaning is determined, following of course, the principle of relevance. To distinguish the enriched logical from a "standard" implicature, Sperber and Wilson (1995) call it an "explicature".

Certainly Michael (1991: 44 - 45) adds that the interpretation of any utterance involves not just determining the propositional form underlying it, but also identifying its relevant context. Clearly, at least in planned discourse, highly relevant context is that established by the propositions underlying the preceding utterances. There are without doubt other contexts available to the listener, but the most accessible contexts are those established by what has preceded.

\section{The Central Claim of Relevance Theory}

Wilson and Sperber (2004: 607) showed that the central claim of RT is that "an utterance raises certain specific and predictable expectations of relevance." These expectations guide the hearer towards the speaker's meaning. Sperber, et al (1995: 50) state that

RT does not claim that communicators always try to be relevant to their hearer, let alone succeed, nor that addressees always trust the communicator to be relevant to them. The crucial claim is this: whether or not the presumption of relevance is warranted, whether or not it is 
accepted, the very fact that it accompanies an utterance helps determine the utterance's intended interpretation. The intended interpretation has to be such that the speaker could think that it would satisfy the expectation of relevance that she /he herself /himself encouraged in the hearer by means of her/his utterance.

\section{The Goal of Relevance Theory}

Wilson and Sperber (1998: 2) argued that the goal of relevance theory is to say "what makes information worth attending to, but without appealing to notions such as topic or interest."

\section{The Main Assumptions of the Current Version of the Theory}

This theory is based on several assumptions: First that every utterance has a variety of possible interpretations, all compatible with the information that is linguistically encoded. Second, that not all these interpretations occur to the hearer simultaneously; some of them take more effort to think up ... The third assumption is that hearers are equipped with a single, very general criterion for evaluating interpretations as they occur to them .... And the fourth, and final, assumption is that this criterion is powerful enough to exclude all but at most a single interpretation, so that having found an interpretation that satisfies it, the hearer need look no further. (Wilson, 1994: 44 - 45)

Sperber and Wilson (2012: 63) said that the processing of an input in the context of existing assumptions may improve the individual's knowledge not only by adding a new piece of information to the existing assumptions, but by revising his/her existing assumptions, or reaching conclusions not derivable from the new piece of knowledge alone but from existing assumptions.

\section{General Rules}

Sperber and Wilson (1995: 265 - 266) say that out of the previous assumptions came two main rules that are considered general but fundamental to 'relevance'. These general rules are:

a) An assumption is relevant to an individual to the extent that the positive cognitive effects achieved when it is optimally processed are large.

b) An assumption is relevant to an individual to the extent that the effort required to achieve these positive cognitive effects is small.

\section{Relevance of an Input to an Individual}

Wilson and Sperber (2004: 609) state that: 
a) Other things being equal, the greater the positive cognitive effects achieved by processing an input, the greater the relevance of the input to the individual at that time.

b) Other things being equal, the greater the processing effort expended, the lower the relevance of the input to the individual at that time.

\section{The Communicative Principle of Relevance}

Sperber and Wilson (1995:58-61) state also that Relevance Theory mentions that there are two levels of intentions in human communication: the informative intention and the communicative intention. A communicator's informative intention is to make a certain set of assumptions manifest to her audience. Her communicative intention is to make the informative intention mutually manifest to her audience and herself.

\section{Optimal Relevance}

Sperber and Wilson (1995:270) mention that an ostensive stimulus is optimally relevant to an audience if it has two properties which are as follow:

a) The ostensive stimulus is relevant enough for it to be worth the addressee's effort to process it.

b) The ostensive stimulus is the most relevant one compatible with the communicator's abilities and preferences.

Noh (2000: 64) explains them as follows: Clause (a) states that the ostensive stimulus (e.g. utterance) should achieve at least enough cognitive effects to justify the processing effort required. Clause (b) takes into account the fact that the speaker may be unable or unwilling to make her utterance more relevant than this, but notes that she will be expected to do so to the extent that she is willing and able to.

\section{Relevance - Theoretic Comprehension Procedure}

Wilson and Sperber (2004:613) state that the procedures of comprehension are:

a) Follow a path of least effort in computing cognitive effects. Consider interpretations (e.g. disambiguation, reference, resolutions, contextual assumptions, and implicatures) in order of accessibility.

b) Stop when your expectations of relevance are satisfied.

c) Wilson and Tim (2006: 1567) state that a hearer using this procedure in interpreting an utterance should (a) pay attention to the most salient aspects of the input, (b) take into consideration the most accessible disambiguation, reference resolutions, contextual assumptions, implicatures, speech act descriptions, and (d) stop when he has an interpretation that contains enough 


\section{DR Abeer Hussein Yousse}

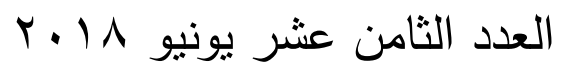

cognitive and contextual effects to satisfy the particular expectation of relevance raised by the utterance.

\section{Sub-Tasks in the Overall Comprehension Process}

a. Constructing an appropriate hypothesis about explicit content (in relevance - theoretic terms, explicatures) via decoding, disambiguation, reference resolution, and other pragmatic enrichment process.

b. Constructing an appropriate hypothesis about the intended contextual assumptions (in relevance - theoretic terms, implicated premises).

c. Constructing an appropriate hypothesis about the intended contextual implications (in relevance - theoretic terms, implicated premises), Wilson \& Sperber (2004: 615).

Carston (2006: 636) mentions that it is clear from the definitions above that the conceptual content of an implicature is extracted wholly by pragmatic inference, while the conceptual content of an explicature is an amalgam of decoded linguistic meaning and pragmatically inferred meaning.

\section{Implicautre \& Explicatures:}

\subsection{Explicatures}

Carston (1998)_mentions that the assumptions (propositional forms) communicated by a speaker fail into two classes: explicature and implicature. Sperber \& Wilson's (1986: 182) original definition of explicitness is as follows:

An assumption communicated by an utterance $U$ is explicit [hence an explicaure'] if it is a development of a logical form encoded by U. Clearly the content of explicatures comes from two important sources, the linguistic expressions and the context, and is derived in two distinct ways, semantic decoding and pragmatic inference. Carston (1998: 118) concludes that by this formula: explicit $=$ encoded and implicit $=$ inferred. Carston (1998: 121) adds that there is a range of pragmatic processes that are required in the recovery of the proposition the speaker intended to express.

Del (1997: 185 -7) also adds that utterance interpretation comprises two processes: one based on coding and decoding and the other on ostension and inference. The hearer's initial task upon hearing an utterance is to flesh out its logical form into a propositional form. This completion process involves doing three basic things assigning reference, disambiguating and eliminating vagueness through concept adjustment, and adjusting certain concepts encoded linguistically in the utterance. In such circumstances, Sperber \& Wilson (1995) call the proposition expressed by the utterance an explicature of the utterance. Assumptions which are communicated by the utterance but which are not a development of its logical form are implicatures. 
Groefsema (1992: 57) adds that in the case of reference assignment, an utterance containing a referential expression, analytically implies that the entity the expression refers to exist. Recovering this implication may be enough to yield adequate contextual effects. In cases of ambiguity, the addressee again goes for the interpretation that is consistent with the principle of relevance. As stated in (Groefsema: p. 52), "if processing costs were no object, the hearer could explore all possible parsings, disambiguations, illocutionary forces, reference assignments and enrichments"

Jodlowiec (2015: 41) concludes that RT is a fully inferential model of communication, in which the linguistic signal used by the communicator is assumed to constitute a piece of evidence stimulus. It is on the basis of this ostensive stimulus that the recipient infers the meaning expressed by the speaker. This means that on the relevance theoretic approach, recovering the explicitly communicated meaning is taken to embrace decoding as well as inferential processes, with the former being an output of the workings of the language and the latter involving hypothesizing from the decoded stimulus to the interpretation which would meet the recipient's expectations of relevance.

\subsection{Implicature:}

Carston (1998:127) implicatures are derived inferentially. For Sperber \& Wilson implicatures (1995) come in two sorts: implicated premises and implicated conclusions. Implicated premises are a subset of the contextual assumptions used in processing the utterance and implicated conclusions are a subset of its contextual implications. Matusi (1995: 46) mentions that Relevance Theory distinguishes three aspects of utterance meaning:

1. What is said (propositional form).

2. What is implied (implicatures).

3. What attitude is communicated in each case.

The first aspect of utterance meaning 'what is said' is called the propositional form in relevance theory. According to Sperber \& Wilson, the propositional form of an utterance goes beyond the encoded linguistic meaning and encapsulates the truth conditional content of the utterance. Tanaka (1989: 213) adds that the speaker tries to take advantage of the fact that he is communicating certain assumptions by implicature, rather than explicature and he is denying his backing for these assumptions, despite the fact that he has ostensively communicated them.

\section{Data Analysis:}

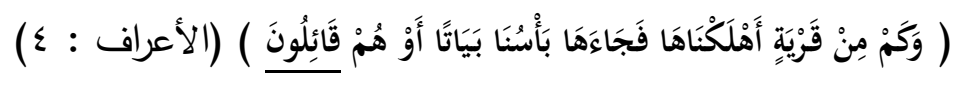


"How many towns have we destroyed (for their sins)? Our punishment took them on a sudden by night or while the [slept for their afternoon rest]". (Qur'an7:4)

In this verse, the hearer treats the events described as temporally or causally related; the events described in the first clause and also the word بياتا "night" help the hearer to recover the implicature and encode the meaning of "قائلون", the hearer may interpret it as the active participle "saying", but it is not correct. He/She should choose the solution involving the least effort to reach the logical form of this verb which is from "sleeping for their afternoon rest".

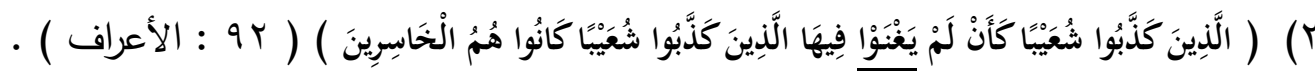

"The men who rejected Shu'ayb became as if they had never been in the homes where they had flourished: the men who rejected Shu'ayb - it was they who were ruined". (Qur'an 7:92)

In order to reach the intended interpretation of the meaning (يغنوا), the hearer should be aware of the contextual effects; the hearer need to select the intended context or the previous assumptions which mentioned in the previous verse. The previous assumptions talk about "the earthquake took them unawares and they lay prostrate in their homes (Qur'an 7: 91).

$$
\text { " فَأَخَخَتْهُمُ الرَّجْفَةُ فَأَصْبَحُوا فِي دَرِِِهْ جَاثِمِينَ الأعراف : }
$$

So depending on this context, and when we follow a path of least effort, the meaning of " يغنوا " should be "never been in the homes." It doesn't mean "never been rich."

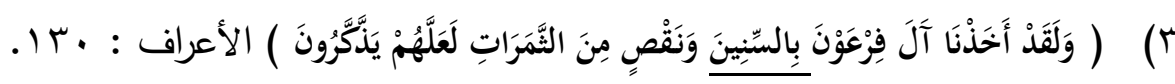

"We punished the people of Pharaoh with years of drought and shortness of crops; that they might receive a dmonition" (Qur'an 7: 130)

In order to recover the intended meaning of the word "سنين", the hearers need to assign values to context-sensitive expressions (e.g. shortness of crops نقص من الثرات النسنين is ambiguous; it may refer to "years" but the specific meaning of the certain lexical item should be years of drought. Jodlowiec (2015:47).

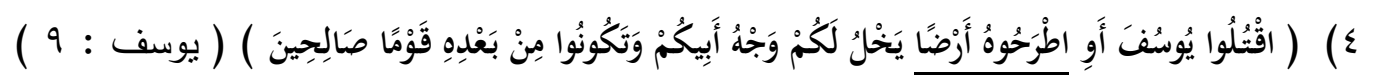

"Kill Yusuf (Joseph) or cast him out to some (other) land, so that the favour of your father may be given to you alone, and after that you will be righteous folk (by intending repentance before committing the sin). (Qur'an 12: 9). 
For the relevance-guided interpretation process of the expression "أرضا, the hearer should follow a path of least effort until he has obtained enough cognitive effects to satisfy his expectation of relevance. First, the hearer needs to select the assumption which will be brought to bear in interpreting the utterance which is [the favour of your father may be given to you alone]. So, this expression has an implicated conclusion which means cast him out to some other land and it doesn't mean "lay him on the ground".

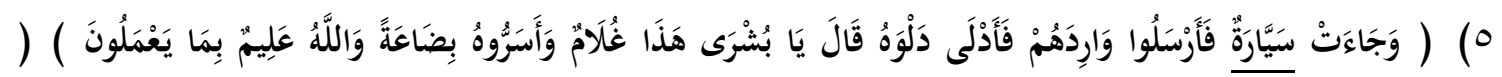

(19) : 19 )

"Then there came a caravan of travellers: they sent their watercarrier (for water)" (Qur'an 12: 19)

In order to recover the truth - conditional content of the word (سيارة), one may think that it implies "any kind of vehicle or it means a car", but this verse has an unresolved reference and the pronoun 'they' gets automatically embedded into a description of the intended meaning of this lexical item which is "travellers" (Jodlowiec: 51).

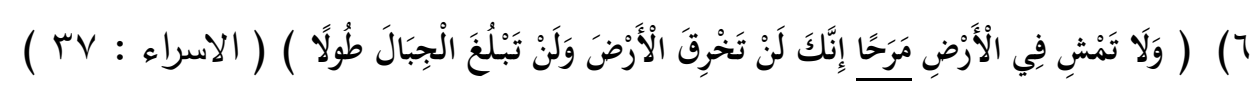

"And walk not on the earth with conceit and arrogance. Verily, you can neither rend nor penetrate the earth, nor can you attain a stature like the mountains in height." (Qur'an 17: 37)

In order to decode the linguistic meaning of the word "مرحا", this word doesn't come from joy and happiness but the hearers should make inference based on contextual assumptions established in this verse (e.g. penetrate the earth or attain a stature like the mountains". So the intend interpretation of this word must be "walk with conceit or arrogance on earth."

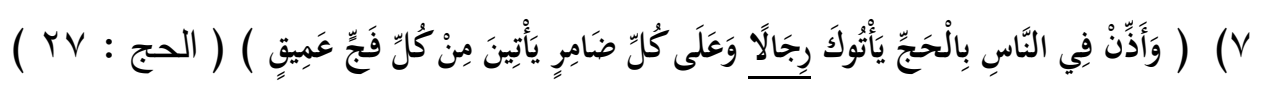

"And proclaim to mankind the Hajj (pilgrimage). They will come to you on foot and on every lean camel, they will come from every deep and distant (wide) mountain highway (to perform Hajj). (Qur'an 22:27)

In this verse, in order to interpret the lexical item "رجالاً", it doesn't mean "males". We should follow a path of least effort in computing cognitive effects and stop when our expectation of relevance is satisfied. The hearer should encounter the sequence of action and the other assumption which is "on every lean" to get access to the intended interpretation of رجالاً which is "coming to you on foot". 


$$
\begin{aligned}
& \text { العدد الثامن عثر يونيو 11 بـr }
\end{aligned}
$$

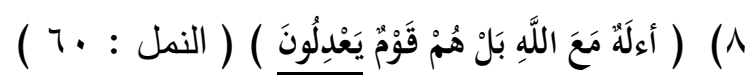

"(Can there be another) god besides Allah? Nay, they are a people who swerve from justice." (Qur'an 27: 60)

In order to recover the explicit content of the word "يعلون".One should know that it doesn't mean "making justice". Hearers should pay attention to assumptions in order to figure out the intended meaning. The ostensive stimulus in the previous assumption at the same verse mentions that أمن خلق السموات والأرض or, "who created the heavens and the earth, and who sends you down rain ..." So, the intended interpretation of the meaning يعلون should be the opposite from the explicit content; it implies "swerve from justice."

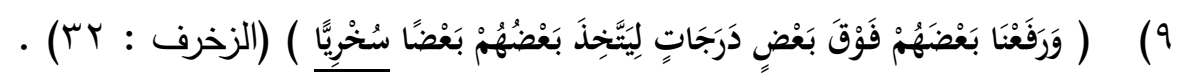

"And we raise some of them Above others in ranks. So than some may command work from others" [Qur'an 43: 32)

The explicit meaning of the word "سخرياً" may be interpreted as "irony or flouted" but that is not true. So, to recover the truth conditional content of this meaning, there is an evidence in the previous assumption which mentions that "Allah portions out between their livelihood in the life of this world نحن قسمنا بينهم " ... This previous assumption may improve the hearer's knowledge by yielding conclusions from the existing assumption to reach to the intended interpretation for the word سخرياً which really means "command work from others".

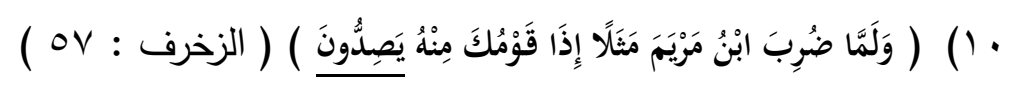

"When (Jesus) the son of Mary is held up as an example, behold your people raise a clamour thereat (in ridicule).

In order to recover the implicit content of "يصدون" the hearers need to disambiguate this word. This word might be understood as "prevent". This possible resolution involves pragmatic inference, without which we will be unable to reach the intended interpretation of the word which is "a clamour thereat in ridicule when the son of Mary is quoted as an example".

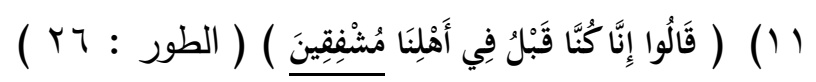

"Saying" A fore time we were afraid (of the punishment of Allah) in the midst of our families" (Qur'an 52: 26)

In order to recover the implied meaning of "مشفقين".One should know that this word is ambiguous. It may mean "pity". The hearers should pay attention to 


\section{DR Abeer Hussein Yousse}

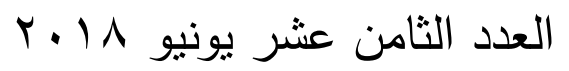

the existing assumptions which improve his/her knowledge by yielding conclusions from the existing assumptions; so the hearers should follow a path of least effort and recognize what is mentioned in the following verse that "Allah has been gracious to us, and has saved us from the torment of the fire (At-tur: 27)

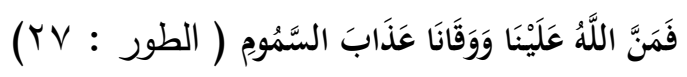

So, the intended meaning of the word مشفقين is "they were afraid of the punishment of Allah."

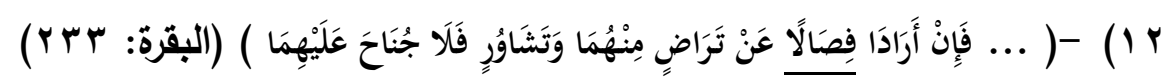

“... If they both decide on weaning by mutual consent, and after due consultation, there is no sin on them. ..." [Qur'an 2: 233].

In order to recover the truth conditional content of "فصالا", the hearers need to disambiguate this word. The hearer may interpret it as "a divorce" but in order to reach to the intended interpretation. The hearers require an appropriate set of contextual assumptions. The hearer should take the decoded linguistic meaning following a path of least effort; he should enrich it at the explicit level and complement it at the implicit level (W \& S 2004: 613). So the previous assumption in this verse says that "The mothers shall give suck to their children for two whole years" (Qur'an2: 233).

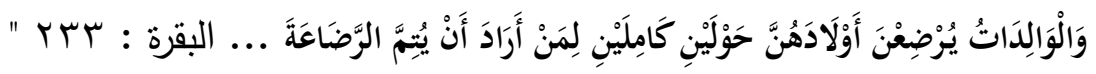

So, the intended interpretation of the word فصالاً should be 'weaning'.

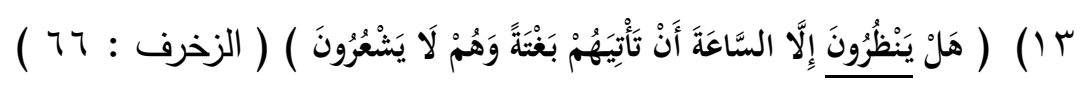

"Do they only wait for the Hour that it shall come upon them suddenly while they perceive not?" (Qur'an 43: 66)

In order to recover the explicit content of the encoded logical form of the word "ينظرون". One should know that this word doesn't mean "watch or see”, but we should improve the hearers knowledge by paying attention to the previous assumption in the preceding verse which mentions "the torment of a painful day (the day of Resurrection) (Al-Zukhruf: 65)

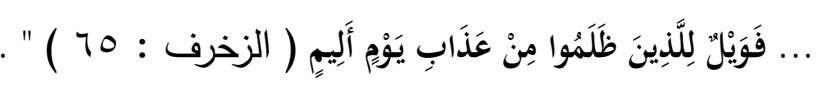

So, the intended meaning of the word ينظرون should be interpreted as "wait".

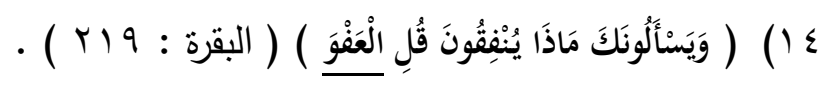

"... And they ask you what they ought to spend. Say: "that which is beyond your needs" (Qur'an 2: 219).

In this verse, the pragmatic inference is required in recovering the explicit truth - conditional content of the word "العفو". It doesn't mean "forgiving", but the 
verb "يفقون" 'spend' in this verse helps the hearer to infer the intended interpretation which satisfies his/her expectation of relevance. This word mean "beyond your needs."

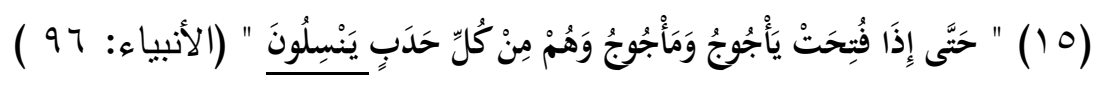

"Until, when Ya'jûj and Ma'juj (Gog and Magog) are let loose. (from their barrier), and they swoop down from every mound." (Qur'an 21: 96)

In order to recover the intended meaning of the word "ينسلون", the interpreter needs to identify the specific meaning of certain lexical items and phrases (e.g. words like 'let loose' and 'mound'). So the explicit meaning of this word may be interpreted as "multiplication or offspring" but the implied meaning is "swoop down".

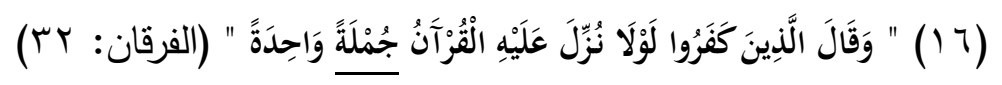

“And those who disbelieve say: Why is not the Qur'an revealed to him all at once.”( Qur'an 25: 32)

The first assumption for the word" جُمْلَمَ " to be accessible to hearers might be "one phrase". But through using additional material from the same verse "Thus (it is sent down in parts), that we have revealed it to you gradually." (Qur'an 25:32)

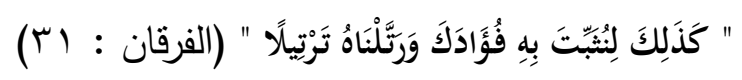

So, the implied meaning for the word "جملة" should be interpreted as "all at once".

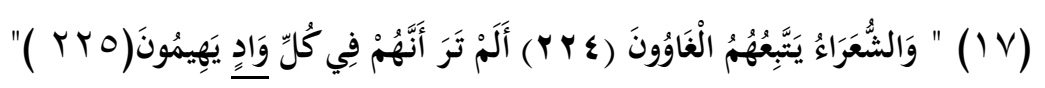

"As for the poets, the erring ones follow them (224), See you not that they speak about every subject (praising people - right or wrong) in their poetry." (Qur'an 26: 224-5)

In order to interpret the meaning of the word gواد", one should realize that it doesn't mean "valley". But the hearer needs to select the intended context (i.e. the set of assumptions which will help to interpret the utterance." So, the following verse (the following assumption) says "And that they say what they do

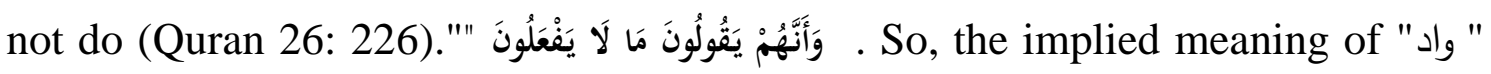
should be interpreted as "speaking about every subject."

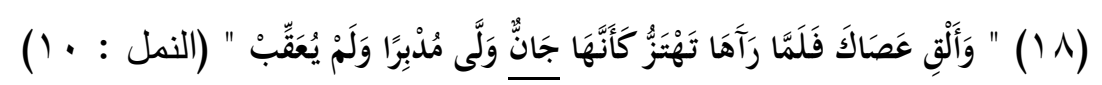

"And throw down your stick. But when he saw it moving as if it were $\underline{\text { a }}$ snake, he turned in flight, and did not look back." (Qur'an 27:10)

Depending to this verse different propositions should be taken into consideration in order to recover the implied meaning of the word "جان". It doesn't 
mean "Jean", but the word "تهنز moving" helps the interpreter to reach the implied meaning which is "a snake".

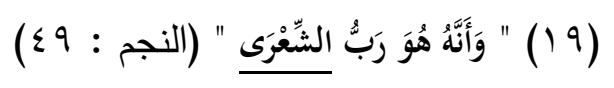

"And that He (Allah) is the lord of Sirius (the star which the pagan Arabs used to worship). (Qur'an 27: 49)

In order to recover the truth conditional content of the word "الثعرى", the interpreter needs to disambiguate the meaning of this word. It doesn't mean poets, but the intended interpretation should be "stars".

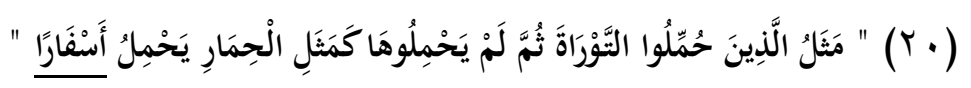

"The likeness of those who were entrusted with the Taurat but who subsequently failed in those, is as the likeness of a donkey which carries huge burdens of books." (Qur'an 62: 5 )

In order to recover the implied meaning of the word " أسفاراً", one should observe that this word doesn't mean "Traveling". But the interpreter needs to assign values to context sensitive expressions (e.g. carry).So, the implied meaning of this word is "book".

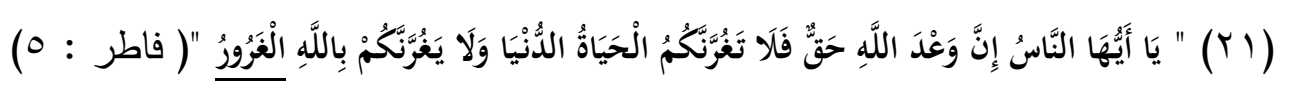

"O mankind! Verily, the promise of Allâh is true. So let not this present life deceives you, and let not the chief deceiver (Satan) deceive you about Allâh." (Qur'an 35: 5)

In order to recover the implied meaning of the word"الغرور", the interpreter needs to disambiguate this word. It doesn't mean "arrogance". The interpreter should follow a path of least effort and pay attention to the previous assumption in the same verse. So the intended meaning is "Satan or anything that deceives us."

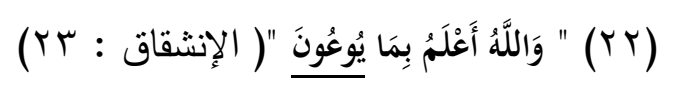

“And Allâh knows best what they gather (of good and bad deeds)."( Qur'an 84: 23)

The truth-conditional content of the word "يوعون" is determined through the relevance-theoretic comprehension strategy. The interpreter should pay attention to the previous contextual assumption and the following assumption in the same surah (Nay, those who disbelieve belie (22) ... so announce to them a painful torment (24). So this word doesn't mean "awareness", but the implied conclusion of this meaning should be "Allah knows what is they gather inside their hearts."

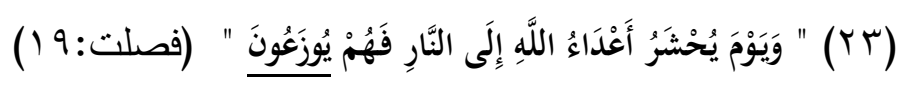


"And (remember) the Day that the enemies of Allâh will be gathered to the fire, then they will be driven (to the fire), former ones being withheld till their later ones will join them." (Qur'an 41: 19)

The explicit meaning of "يوزعون" might be understood as "to distribute". But the interpreter needs to assign values to context - sensitive expressions (e. g. gather). So the implied meaning of this word should be "the former ones being withheld till the later ones."

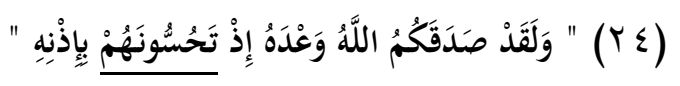

"And Allâh did indeed fulfill His promise to you when you were killing them (your enemy) with His permission." (Qur'an 3: 52)

In order to recover the implied meaning of "تحسونهم" the interpreter needs to disambiguate this word.It doesn't come from feeling or sense but the interpreter should pay attention to the previous assumption in the same surah "we shall cast terror into the hearts of those who disbelieve ... Qur'an 3: 151." So, the implied meaning of this world is to "kill them".

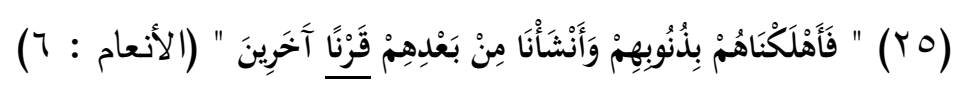

"Yet we destroyed them for their sins, and we created after them other generations." (Qur'an 6:6)

In order to decode the linguistic content of the meaning, "قرناً".One may think that it implies "century". But the interpreter needs to assign values to expressions like "destroy". So the implied meaning of this word should be "generation." 


\section{Table 1: Implicit/Explicit Meanings and the Comprehension} Procedures Used to Achieve Relevance

\begin{tabular}{|c|c|c|c|c|}
\hline $\begin{array}{r}\text { No. Surah } \\
\text { and No. } \\
\text { Verse }\end{array}$ & Word & $\begin{array}{l}\text { Explicit } \\
\text { Meaning }\end{array}$ & $\begin{array}{l}\text { Implied } \\
\text { Meaning }\end{array}$ & 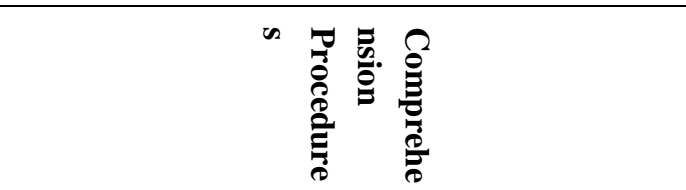 \\
\hline $\begin{array}{r}\text { Surah 7: } \\
4\end{array}$ & قائلون & saying & $\begin{array}{l}\text { Sleeping for } \\
\text { their } \\
\text { afternoon } \\
\text { rest }\end{array}$ & $\begin{array}{l}\text { Recovering the implicature through } \\
\text { using contextual assumptions. }\end{array}$ \\
\hline $\begin{array}{r}\text { Surah 7: } \\
92\end{array}$ & يغتوا & $\begin{array}{l}\text { Never been } \\
\text { rich }\end{array}$ & $\begin{array}{l}\text { Never been } \\
\text { in the homes }\end{array}$ & Using contextual effects \\
\hline $\begin{array}{r}\text { Surah 7: } \\
13\end{array}$ & 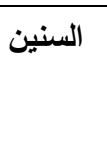 & Years & $\begin{array}{l}\text { Years of } \\
\text { drought }\end{array}$ & $\begin{array}{l}\text { Constructing an appropriate hypothesis } \\
\text { about explicit content via } \\
\text { disambiguation. }\end{array}$ \\
\hline $\begin{array}{r}\text { Surah 12: } \\
9\end{array}$ & أرضاً & $\begin{array}{l}\text { Lay him on } \\
\text { the ground }\end{array}$ & $\begin{array}{l}\text { Cast him out } \\
\text { to some } \\
\text { other land }\end{array}$ & $\begin{array}{l}\text { Constructing an appropriate hypothesis } \\
\text { about the intended contextual implication }\end{array}$ \\
\hline $\begin{array}{r}\text { Surah 12: } \\
19\end{array}$ & 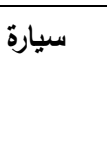 & $\begin{array}{l}\text { Any kind of } \\
\text { vehicle or a } \\
\text { car }\end{array}$ & Travellers & $\begin{array}{l}\text { Constructing an appropriate } \\
\text { about explicit content via rethesis } \\
\text { resolution }\end{array}$ \\
\hline $\begin{array}{r}\text { Surah 17: } \\
37\end{array}$ & 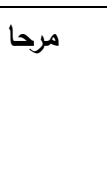 & $\begin{array}{l}\text { Happiness or } \\
\text { Joy }\end{array}$ & $\begin{array}{l}\text { Walk with } \\
\text { conceit or } \\
\text { arrogance on } \\
\text { earth }\end{array}$ & $\begin{array}{l}\text { Decoding the linguistic meaning via making } \\
\text { inference based on contextual assumptions }\end{array}$ \\
\hline $\begin{array}{r}\text { Surah 22: } \\
27\end{array}$ & 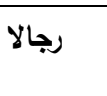 & Males & $\begin{array}{l}\text { Come to you } \\
\text { on foot }\end{array}$ & $\begin{array}{l}\text { Computing cognitive effects about the } \\
\text { intended contextual assumptions }\end{array}$ \\
\hline $\begin{array}{r}\text { Surah 27: } \\
60\end{array}$ & يعدلون & $\begin{array}{l}\text { Making } \\
\text { justice }\end{array}$ & $\begin{array}{l}\text { Swerve from } \\
\text { justice }\end{array}$ & $\begin{array}{l}\text { Constructing an appropriate hypothesis } \\
\text { about the contextual assumptions }\end{array}$ \\
\hline $\begin{array}{l}\text { Surah } \\
\text { 43: } 32\end{array}$ & 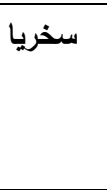 & $\begin{array}{l}\text { Irony } \quad \text { or } \\
\text { Flouted }\end{array}$ & $\begin{array}{l}\text { Some } \\
\text { command } \\
\text { work from } \\
\text { others }\end{array}$ & Using contextual assumptions \\
\hline $\begin{array}{r}\text { Surah 43: } \\
57\end{array}$ & يصدون & Preventing & $\begin{array}{l}\text { a clamour } \\
\text { thereat in } \\
\text { ridicule }\end{array}$ & $\begin{array}{l}\text { Constructing a hypothesis about explicit } \\
\text { content via disambiguation }\end{array}$ \\
\hline $\begin{array}{l}\text { Surah } \\
52: 26\end{array}$ & مشفقين & Pity & $\begin{array}{l}\text { Afraid of the } \\
\text { punishment } \\
\text { of Allah }\end{array}$ & $\begin{array}{ll}\text { - } & \text { Constructing a hypothesis about } \\
\text { explicit content via disambiguation }\end{array}$ \\
\hline $\begin{array}{r}\text { Surah 2: } \\
233\end{array}$ & فصالا & Divorce & Weaning & $\begin{array}{l}\text { Decoding the linguistic meaning via } \\
\text { disambiguation }\end{array}$ \\
\hline $\begin{array}{r}\text { Surah 43: } \\
43\end{array}$ & ينظرون & Watch or See & Wait & $\begin{array}{l}\text { Decoding the logical form via contextual } \\
\text { assumptions }\end{array}$ \\
\hline $\begin{array}{r}\text { Surah 2: } \\
219\end{array}$ & العفو & Forgiving & $\begin{array}{l}\text { Beyond your } \\
\text { needs }\end{array}$ & pragmatic inference \\
\hline $\begin{array}{r}\text { Surah 21: } \\
96\end{array}$ & 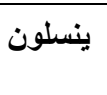 & $\begin{array}{l}\text { Multiplication } \\
\text { or Offspring }\end{array}$ & Swoop down & Pragmatic enrichment \\
\hline $\begin{array}{r}\text { Surah 25: } \\
32\end{array}$ & جملة & One phrase & All at once & contextual assumptions \\
\hline
\end{tabular}




\begin{tabular}{|c|c|c|c|c|}
\hline $\begin{array}{r}\text { Surah 26: } \\
225\end{array}$ & واد & Valley & $\begin{array}{l}\text { Speaking } \\
\text { about every } \\
\text { subject }\end{array}$ & contextual assumptions (Implicated Premise) \\
\hline $\begin{array}{r}\text { Surah 27: } \\
10\end{array}$ & جان & Jean & Snake & decoding \\
\hline $\begin{array}{r}\text { Surah 27: } \\
49\end{array}$ & الشعرى & Poets & Star & disambiguation \\
\hline $\begin{array}{r}\text { Surah 62: } \\
5\end{array}$ & أسفاراً & Traveling & Book & reference resolution \\
\hline $\begin{array}{r}\text { Surah 35: } \\
5\end{array}$ & 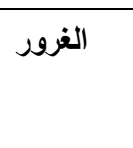 & Arrogance & $\begin{array}{l}\text { Satan or } \\
\text { Anything } \\
\text { deceive us }\end{array}$ & disambiguation \\
\hline $\begin{array}{r}\text { Surah 84: } \\
23\end{array}$ & 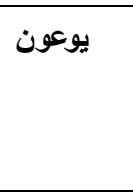 & Awareness & $\begin{array}{l}\text { Allah knows } \\
\text { what they } \\
\text { gather inside } \\
\text { their hearts }\end{array}$ & contextual assumptions \\
\hline $\begin{array}{r}\text { Surah 41: } \\
19\end{array}$ & يوزعون & Distribute & $\begin{array}{l}\text { The former } \\
\text { ones being } \\
\text { withhold till } \\
\text { the later } \\
\text { ones }\end{array}$ & reference resolution \\
\hline $\begin{array}{r}\text { Surah 3: } \\
152\end{array}$ & تحسونهم & $\begin{array}{ll}\text { Feeling } & \text { or } \\
\text { Sense } & \end{array}$ & Kill them & disambiguation \\
\hline $\begin{array}{r}\text { Surah 6: } \\
6\end{array}$ & قرناً & Century & Generations & decoding and reference resolution \\
\hline
\end{tabular}

\section{Findings and Conclusion:}

From the previous interpretations of the verses of the Holy Qur'an, it is obvious that the comprehension processes are required in order to resolve the disambiguation, reference assignment and the recovery of ellipsed material and pragmatic enrichment. All these processes help the hearers to obtain enough cognitive effects to satisfy their expectation of relevance and reach the intended interpretation of the meanings of the verse.

- The comprehension procedures used above in the interpretation of the meanings of the Qur'an confirm the importance of accessing appropriate contextual assumptions and making hypotheses about what is explicitly communicated as well as constructing hypotheses about the intended implicatures. This procedure helps hearers to reach the implied meanings of the Qur'an (Carston and Hall 2012: 69).

- The intended interpretations of the meanings of the Qur'an result from the hearers following the shortest path to achieve a satisfying level of cognitive effect, which helps the hearers to reach the exact meanings of the ambiguous words. 
- It is interesting to note that identifying the intended meanings of the verses requires determining the explicit content and the cognitive effects (i.e. Implicated conclusions).

- It is important also to note that decoding the linguistic meanings of the verses requires using the available contextual and inferential resources and identifying the meanings via processes of disambiguation, reference assignment and pragmatic enrichment.

- Finally, an optimal relevant interpretation of the Qur'an emerges in the course of mutual adjustments among hypotheses about the explicit and implicit content communicated which are confirmed in the course of interpretation through using the comprehension procedure processes and through using the contextual assumptions (Jodlowiec 2015: 48).

"دراسة لغوية للتمييز بين المعانى الواضحة و الضمنية فى معانى بعض الآيات القرآنية"

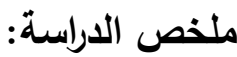

بعض الكلمات بالآيات القرآنية تفهم معانيها بثكل خاطئ ولذلك تهدف هذه الدراسة إلى التعرف

على كيفية التوصل إلى التفسير الأمتل من خلال الوصول إلى المعانى الواضحة والضمنية لتلك الكلمات بإستخدامً نظرية النواصل لسبربر وويسلون(919 19901) ، وكيفية التوصل إلى التفسير الأمتل لتلك المعانى من خلا إجراءات الفهم المستخدمة من قبل نظرية سبربر وويلسون والتى تحتوى على إزالة الغموض والتوصل إلى المعنى الواضح والضمنى باستخدام الاقتراحات النصية المسبقة لتحديد تلك المعانى

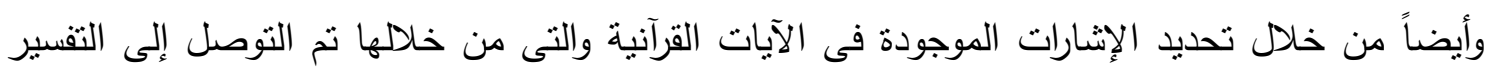
الأمتل لتلك المعانى وإزالة الغوض المنتبط ببعضها. 


\section{References}

Carston, Robyn. 1998. "Pragmatics and the Explicit/Implicit Distinction." $\mathrm{Ph}$. D. thesis, University College, London.

Carston, R. 2006. Relevance Theory and the Saying/Implicating Distinction. In

L. Horrn \& G. Ward (Eds.) Handbook of Pragmatics. (pp.633-656). Oxford: Blackwell.

Carson,Robyn \& Alison Hall. 2012. Implicature and Explicature, Cognitive Pragmatics (Vol.4). Ed. Hans-Jorg Schmid.

Cook, J. 2005. A Pragmatic Analysis of Irony. Language and Information Society 6,18-35.

Del Carmen Curco Cobos, Maria. 1997. "The Pragmatics of Humorous Interpretation: A Relevance-theoretic approach" Ph. D. thesis. University of Amsterdam.

Dor, D. 2003. On Newspaper headlines as relevance optimizers. Journal of Pragmatics, 35 (5), 695-721.

El-Sharif, A. 2011. "A Linguistic study of Islamic religious discourse: Conceptual metaphors in the prophetic tradition". Ph. D. Thesis. Queen Mary, University of London.

Groefsema, Magjolein. 1992. "Processing for relevance: A pragmatically- based account of how we process natural language". Ph. D. thesis, University College, London.

Jodlowiec, Maria. 2015. The challenges of Explicit and implicit communication: A Relevance-Theoretic approach. (Vol.11). ED. Elzbieta Chzanowska Kluczewska.

Matsui, Tomok. 1995. "Bridging and Relevance", Ph. D. thesis, University of London.

Michael ,0. 2011. "Applying relevance theory to news media headlines: Measuring the relevance of television's "Breaking News Alert". M. A. Thesis, Faculty of Graduate School, Austin State University.

Michael Kenkel, J. 1991. "Argumentation pragmatics, text analysis, and contrastive rhetoric". Ph. D. Thesis: University of Illinois at UrbanaChampaign, Urbana, Illinois.

Noh, Eun-Ju. 1998. "The semantics and pragmatics of Metarepresentation in English: A Relevance-Theoretic approach " $\mathrm{Ph}$. D. thesis, University College, London. 
Noh, E, J. 2000. Metarepresentation: A relevance-theory approach. JohnAmsterdam, Philadelphia: Benjamins Publishing Company.

Sperber, D. and Wilson, D. 1986. Relevance: Communication and Congition. Oxford: Blackwell.

Sperber, D. and Wilson, D. 1987. Precis of Relevance: Communication and cognition. Behavioral and Brain Science 10: 697-754.

Sperber, D. and Wilson, D. 1995. Relevance: Communication and Cognition. Oxford: Blackwell.

Sperber, D. and Wilson, D. 2012. "Truthfulness and relevance". In Wilson, D \& and Sperber, D. Meaning and Relevance. Cambridge University Press, pp.47-83

Sperber, D. and Wilson, D. 2012." Rhetoric and relevance".In Wilson, D \& Sperber, D. Meaning and Relevance. Cambridge: University Press, pp. 84-96

Sperber, D., Francesco, C. \& Vittorio, G. 1995. Relevance theory explains the selection task. Cognition 57. pp 31-95.

Tanaka, Keiko. 1989. “The language of advertising: a pragmatic approach" $\mathrm{Ph}$. D. thesis, university of London.

Taqi-ud-Din Al-Hilali, Muhammad. "Translation of the meaning of the Noble Qur'an in the English language".

Wilson, D. 1994. "Relevance and understanding". In G. Brown, K. Malmokjaer, A. Pollitt and J. Williams, eds., Language and understanding. Oxford: Oxford University Press. PP.35-58

Wilson, D. 1999. "Relevance and relevance theory". In: MIT Encyclopedia of Cognitive Science (MITECS). Eds. R. Wilson and F. Keil. Cambridge, Mass: MIT Press, 719-722.

Wilson, D. 2004. "Relevance theory and lexical pragmatics". Italian Journal of Linguistics/Rivista di Linguistica, 15, 2, Special Issue on Pragmatics and the Lexicon.

Wilson, D.and Sperber, D. 1988. "Mood and the analysis of non-declarative sentences". In Dancy,Moravczik and Taylor.

Wilson, D.and Sperber, D. 2002. Relevance theory. UCLA Working Papers in Linguistics 14:248-290.

Wilson, D. and Sperber, D. 2004. "Relevance Theory". In: L. Horn and G. Ward (Eds.) The Handbook of Pragmatics. 607-632, Oxford: Blackwell. 
DR Abeer Hussein Yousse العدد الثامن عثر يونيو 11 بـr

Wilson, D. \& Whaton,T. 2006. "Relevance and Prosody". Journal of Pragmatics 38 (2006). 1559 - 1579.

Yusuf Ali, Abdullah: “The Meaning of the Holy Qur'an", Amana Publications .

Zhonggang, S. 2006. "A relevance theory perspective on Translating the implicit information in literary texts". Journal of Translation, Vol. 2, No. 2, pp.43-60. 